\title{
PELATIHAN BERPIKIR POSITIF TERHADAP KONSEP DIRI REMAJA YANG TINGGAL DI PANTI ASUHAN
}

\author{
Dhea Ravea Eka Putri \\ Fakultas Psikologi, Universitas Muhammadiyah Malang \\ Emai:ldhearaveaa@gmail.com
}

\begin{abstract}
Self-concept is an individual view about their self based on a variety of experiences during their life. This topic is interesting to be examined in orphanage context, because adolescents have various experiences in their life before and during their stay in the orphanage. Aim of this study was to understand the role of positive thinking training on adolescents' self-concept who lived in an orphanage. This research was quasi-experimental with nonrandomized pre-test post-test control group design model. Measuring instruments used self-concept scale. Subjects of this study were 30 adolescents who live in Al-Hidayah Batu orphanage, and were in the age range 13-17 years and have low and medium selfconcept score category. Subject selection technique used purposive sampling. However, for subject's classification on experimental and control group used random sampling method. Analysis used Independent Sample t-Test, and $p=0,003(p<0,05)$. The conclusion was positive thinking training could improve self concept of adolescents who lived in orphanages.
\end{abstract}

Keywords: positive thingking training, self concept, orphanage, adol

\section{INTISARI}

Konsep diri merupakan pandangan individu terhadap diri yang disebabkan oleh berbagai pengalaman yang pernah dilalui semasa hidup. Topik ini menjadi menarik untuk diteliti ketika subjek penelitian adalah remaja yang tinggal di panti asuhan. Konsep diri dapat ditingkatkan dengan pemberian intevensi pelatihan berpikir positif. Tujuan penelitian ini untuk mengetahui peran pelatihan berpikir positif terhadap konsep diri remaja yang tinggal di panti asuhan. Penelitian ini merupakan penelitian quasiexperimental dengan model non randomized pre-test post-test control group design. Alat ukur yang digunakan adalah skala konsep diri. Subjek penelitian berjumlah 30 remaja yang tinggal di panti asuhan Al-Hidayah Batu yang berada pada rentang usia 13-17 tahun dan memiliki kategori skor konsep diri rendah. Pengambilan subjek diperoleh menggunakan teknik purposive sampling. Sedangkan pembagian subjek ke dalam kelompok eksperimen dan kelompok kontrol menggunakan teknik random assigment. Hasil analisis data menggunakan Independent Sampel t-Test, menunjukkan nilai $p=0.003$ $(\mathrm{p}<0,05)$. Dengan demikian dapat disimpulkan bahwa pelatihan berpikir positif dapat meningkatkan konsep diri remaja yang tinggal di panti asuhan .

Kata kunci: pelatihan berpikir positif, konsep diri, panti asuhan, remaja 
$\mathrm{M}$ asa remaja adalah masa yang menyenangkan sekaligus tersulit dalam perjalanan kehidupan individu. Pada periode ini pula remaja mulai melepaskan diri secara emosional dari orang tua dalam rangka menjalankan peran sosialnya yang baru sebagai orang dewasa (Agustiani, 2006). Saat anak tumbuh menjadi seorang remaja, orang tualah yang seharusnya memiliki peranan besar untuk mendampingi anak dalam melewati masa-masa krisis remajanya (Peter, 2015). Namun, pada kenyataannya tidak semua remaja dapat tinggal, memiliki dan diinginkan oleh orang tuanya. Banyak diantaranya dititipkan di panti asuhan dengan berbagai alasan. Remaja yang tinggal di panti asuhan pada umumnya mengalami shock di awal mereka terpisah dari orang tua, namun shock atau keterkejutan itu merupakan respon yang normal dalam kondisi tersebut (Parry, 1990). Mereka juga mengalami penolakan, stigmatisasi, berhenti dari sekolah, perpindahan dari rumah baru serta perpisahan dengan teman dan saudarasaudara (Mutambara, 2015). Keadaankeadaan tersebut merupakan suatu hambatan yang dialami anak saat pindah ke panti asuhan. Pengalaman-pengalaman yang diperoleh remaja selama tinggal di panti asuhan akan berpengaruh terhadap pembentukan konsep diri. Pengharapan yang dimiliki pada dirinya, akan menentukan bagaimana remaja bertindak dalam kehidupannya, karena pengharapan mengenai diri merupakan suatu konsep diri atau ramalan yang dipersiapkan untuk diri sendiri (Calhoun \& Accocella, 1990).

Calhoun dan Accocella (1990) mengemukakan ada 4 faktor yang mempengaruhi pembentukan konsep diri yaitu: faktor orang tua, berdasarkan data yang diperoleh di panti asuhan Al-hidayah Batu, $70 \%$ dari remaja masih memiliki orang tua namun mereka dititipkan di panti asuhan karena berbagai faktor antara lainnya: keadaan ekonomi orang tua yang kurang dan masalah-masalah keluarga. Temuan ini didukung oleh (Gursoy dkk.., 2012) bahwa remaja yang hidup di panti asuhan memiliki konsep diri rendah daripada remaja yang tidak tinggal di panti asuhan. Hal ini disebabkan karena remaja yang tinggal di panti asuhan mengalami kesepian tanpa dukungan dari keluarga dalam menjalani periode masa remajanya.

Faktor kedua adalah teman sebaya, berdasarkan data yang diperoleh di panti asuhan Al-hidayah Batu, seluruh remaja tinggal dan menghabiskan waktu secara bersama-sama setiap hari dari bersekolah, bermain dan mengerjakan tugas. Mereka tidak banyak memiliki teman di luar sesama anak panti asuhan karena mereka bersekolah di yayasan yang sama. Berdasarkan penelitian (Lukman, 2000) remaja panti asuhan berpotensi untuk memiliki konsep diri cenderung negatif karena adanya pengaruh negatif yang berasal dari lingkungan internal asrama yaitu pergaulan antar sesama anak asuh.

Faktor ketiga adalah masyarakat, menurut Calhoun dan Acocella (1990) penilaian dan pengarapan masyarakat dapat mempengaruhi pembentukan konsep diri. Berdasarkan hasil wawancara yang diperoleh dengan salah satu remaja berinisial (HL) di pati asuhan Al-hidayah, tinggal di panti asuhan masih menjadi hal yang membuatnya tidak percaya diri berada di lingkungan luar panti asuhan karena merasa menjadi anak yang berasal dari keluarga yang tidak mampu menghidupinya.

Hal ini didukung oleh temuan (Lukman, 2000) bahwa anak anak panti asuhan telah mendapatkan label dari masyarakat bahwa mereka merupakan anak-anak yang perlu dikasihi. Artinya, label yang muncul secara internal yang didukung oleh pandangan lingkungan sosialnya.

Faktor keempat adalah hasil belajar, menurut Calhoun dan Acocella (1990) konsep diri merupakan hasil belajar yang berlangsung terus menerus setiap hari dan tanpa disadari. Berdasarkan hasil wawancara yang diperoleh dengan pengurus panti asuhan Al-Hidayah, diperoleh hasil remaja yang titipkan di panti memiliki berbagai permasalahan sosial, sebelum dititipkan di panti. Beberapa dari mereka menyadari bahwa mereka dititipkan di panti oleh orang tua dan beberapa juga dibohongi oleh orang 
tuanya sebelum dititipkan di panti asuhan. Hal ini didukungan dengan hasil wawancara peneliti dengan beberapa remaja di panti asuhan Al-Hidayah, bahwa mereka memerlukan waktu belajar yang lama untuk memahami alasan dari orang tua untuk menitipkan mereka di panti asuhan. Hal ini didukung oleh temuan (Mayaza \& Supradewi, 2011) bahwa remaja panti asuhan cenderung percaya bahwa penderitaan atau kejadian yang tidak menyenangkan akan berlangsung lama dan mempengaruhi kehidupannya, mereka juga cenderung berpikir negatif sehingga menambah rasa ketidakberdayaannya.

Panti asuhan merupakan salah satu lembaga perlindungan anak yang berfungsi untuk memberikan perlindungan terhadap hak-hak anak (Departemen Sosial RI, 2004). Tujuan didirikannya panti asuhan yaitu berusaha untuk memenuhi kebutuhan dasar anak asuh (PPK, 2009). Menurut Departemen Sosial RI (dalam PPK, 2009) bahwa yang bertempat tinggal di panti asuhan adalah anak terlantar. Adapun penyebab anak terlantar menurut BKPA (dalam PPK, 2009) adalah 1) orang tua meninggal dan atau tidak ada sanak keluarga yang merawat sehingga anak menjadi yatim piatu. 2) orang tua tidak mampu (Sangat miskin) sehingga tidak dapat memenuhi kebutuhan minimal anakanaknya. 3) orang tua yang tidak dapat dan tidak sanggup melaksanakan fungsinya dengan baik atau dalam waktu relatif lama misalnya menderita penyakit kronis dan lain-lain. Menurut data yang diperoleh dari badan pusat statistik (BPS, 2016) Provinsi Jawa Timur pada tahun 2012 jumlah anak terlantar usia 5-17 tahun sebanyak 246.665 yang terbagi dari laki-laki sejumlah 128.050 dan perempuan sebanyak 120.615 .

Meskipun panti asuhan telah menjamin pemenuhan kebutuhan individu yang tinggal disana, namun mereka kurang memperoleh perhatian, kasih sayang maupun bimbingan karena pengasuh harus berbagi kasih sayang dan perhatian dengan anak asuh yang lain (Rola, 2006). Hal ini sesuai dengan data yang diperoleh peneliti dari ketua yayasan panti asuhan Al-Hidayah Batu Bapak (GH) menyebutkan bahwa jumlah pengasuh yang sedikit dibandingkan dengan jumlah anak asuh dari usia anak-anak hingga remaja membuat pengasuh tidak dapat memperhatikan anak-anak satu persatu secara intensif.

Berdasarkan penelitian-penelitian yang dilakukan sebelumnya dan data yang diperoleh peneliti di lapangan, remaja yang tinggal di panti asuhan pada umumnya mengalami shock (Parry, 1990); penolakan, perpindahan dari rumah baru, perpisahan dengan teman dan saudara lingkungan (Mutambara, 2015); pertemanan sesama anak panti dan label negatif dari masyarakat (Lukman, 2000); kesepian tanpa keluarga dan berpikiran negatif mengenai kehidupannya (Mayaza \& Supradewi, 2011) serta kurangnya perhatian dari pengasuh (Rola, 2006). Berbagai pengalaman-pengalaman yang pernah dialami remaja panti asuhan dapat mempengaruhi pembentukan konsep diri (Calhoun \& Accocella, 1990).

Oleh karena itu, dibutuhkan sebuah metode untuk dapat meningkatkan konsep diri remaja panti asuhan. Salah satunya menggunakan intervensi kelompok. Intervensi kelompok merupakan suatu upaya mengubah perilaku, pikiran dan perasaan individu yang menekankan interaksi interpersonal dengan semua individu yang terlibat di dalam kelompok Burligame dan Baldwin (dalam Pomarentz, 2013). Adapun intervensi kelompok yang diberikan pada penelitian ini melalui pelatihan berpikir positif. Pelatihan berpikir positif dapat dideskripsikan sebagai suatu upaya intervensi kognitif yang lebih menekankan pada sudut pandang dan emosi yang positif, baik terhadap diri sendiri, orang lain maupun situasi yang dihadapi (Elfiky, 2015).

Berikut merupkan penelitianpenilitian mengenai pelatihan berpikir positif yang pernah dilakukan oleh peneliti sebelumnya. Penelitian yang dilakukan oleh (Hidayat dkk., 2013) mengenai pelatihan berpikir positif terhadap konsep diri remaja difabel. Hasilnya menunjukkan bahwa pelatihan berpikir positif efektif dapat meningkatkan konsep diri remaja difabel. Hasil penelitian tersebut didukung oleh (Arya dkk., 2013) mengenai cognitive behavioral training untuk meningkatkan konsep diri dan sikap positif pada 
tahanan yang kecanduan terhadap narkoba. Hasilnya diperoleh cognitive behavioral training efektif meningkatkan konsep diri pada tahanan pecandu narkoba. Mohammadi dan Adam (2013) juga melakukan penelitian terkait efektivitas pelatihan ketrampilan berpikir positif terhadap kebahagiaan siswa. Hasil penelitian ini mengungkapkan bahwa intervensi pelatihan berpikir positif efektif meningkatkan kebahagiaan pada siswa. Hasil penelitian ini sesuai dengan pemaparan Damayanti dan Purnamasari, (2011) bahwa Individu yang menilai dirinya positif cenderung bahagia, sehat, berhasil dan dapat menyesuaikan diri.

Kemudian Shokmgar (2016) melakukan penelitian terkait efektifitas ketrampilan berpikir positif terhadap kesehatan mental dan harga diri pada siswa. Hasilnya menunjukkan bahwa ketrampilan berpikir positif efektif dapat meningkatkan kesehatan mental dan harga diri pada siswa dalam kelompok eksperimen dibandingkan dengan kontrol. Hal ini sesuai dengan pemaparan dari Brooks (dalam Rahkmat, 2007) bahwa individu yang memiliki konsep diri positif akan mampu menghargai dirinya sendiri dan melihat hal-hal yang positif yang dapat dilakukan demi keberhasilan di masa yang akan datang. Selanjutnya, (Mousavi dkk., 2015) melakukan penelitian mengenai pengaruh pelatihan berpikir positif terhadap kualitas hidup dan resiliensi pasien kanker. Hasilnya menunjukkan pelatihan berpikir positif efektif untuk meningkatkan kualitas hidup dan resiliensi pada pasien kanker. Hal ini didukung oleh penelitian (Amalia, 2015) bahwa semakin positif konsep diri resiliensi remaja, maka semakin baik pula konsep dirinya sebaliknya semakin negatif konsep diri maka resiliensinya akan semakin buruk. Selanjutnya, (Ghaderi \& Barzigar, 2015) melakukan penelitian mengenai pengaruh pelatihan berpikir positif terhadap penyesuaian sosial remaja. Hasilnya menunjukkan remaja yang dilatih berpikir positif memiliki penyesuaian sosial yang lebih baik dibandingkan yang tidak dilatih. Berdasarkan hasil penelitian (Nurhadi, 2013) bahwa remaja yang mampu menerima diri dan keadaannya, lebih mudah melakukan penyesuaian diri.

Berdasarkan penelitian-penelitian yang telah dilakukan, telah terbukti bahwa pelatihan berpikir positif efektif untuk menangani permasalahan-permasalahan yang dialami kelompok seperti: konsep diri remaja difabel, kebahagiaan siswa, kesehatan mental dan harga diri siswa, kualitas hidup dan resiliensi pasien kanker serta penyesuaian sosial pada remaja. Pelatihan berpikir positif merupakan pendekatan yang berfokus pada bakat dan kemampuan individu bukan kelainan atau gangguannya (Mousavi dkk., 2015). Menurut Elfiky (2015) latihan berpikir positif adalah latihan ketrampilan yang dapat membantu seseorang dalam memandang dirinya dan orang lain dengan menekankan sudut pandang dan emosi yang positif. Ellis (dalam Corey, 2015) menjelaskan bahwa manusia memiliki kesanggupan untuk berpikir, maka manusia mampu melatih dirinya sendiri untuk mengubah atau menghapus keyakinankeyakinan yang menyabotase diri sendiri.

Pelatihan berpikir positif akan dilakukan pada kelompok remaja panti asuhan yang memiliki konsep diri negatif, memiliki usia yang tidak jauh berbeda dan tinggal bersama dalam panti asuhan. Hal ini akan mendorong remaja panti asuhan untuk saling menguatkan antara satu sama lainnya dalam upaya meningkatkan konsep diri masing-masing. Menurut Agung, (2000) suatu kelompok terbentuk dari kumpulan individu yang saling berinteraksi antara satu sama lain. interaksi tersebut akan berimplikasi pada perubahan perilaku dan psikologis anggota kelompok. Karena remaja cenderung mengikuti kebiasaankebiasaan yang berlaku di kelompoknya. Penggunaan kelompok teman sebaya akan memudahkan peserta dalam membentuk dinamika di dalam kelompok, sehingga dapat mempengaruhi peningkatan konsep diri.

Dari berbagai pemaparan diatas bahwa penggunaan kelompok teman sebaya dalam upaya pelatihan bepikir positif dapat membantu remaja yang tinggal di panti asuhan untuk bersamasama membentuk keyakinan baru yang lebih positif. Sehingga, pelatihan berpikir 
positif mampu meningkatkan konsep diri pada remaja panti asuhan. Maka tujuan penelitian ini yaitu untuk mengetahui peran pelatihan berpikir positif terhadap konsep diri remaja yang tinggal di panti asuhan. Adapun pentingnya pelatihan ini dilakukan agar remaja yang tinggal di panti asuhan dapat memandang diri dan kehidupannya secara lebih baik, serta dapat mencegah dampak dari pikiran negatif terhadap perilaku yang akan timbul dikemudian hari. Berdasarkan kegunaan praktis dan cepat, dapat digunakan di berbagai kalangan. Adapun berbagai manfaat yang dapat didapatkan dari penelitian ini berupa manfaat teoritis dan praktis. Manfaat teoritis yang dapat didapatkan yaitu dalam penelitian ini diharapkan mampu mengembangkan metode intervensi kelompok dalam ilmu psikologi terutama pada pendekatan psikologi kognitif. Selain itu, manfaat praktisnya diharapkan ketrampilan berpikir positif dapat diterapkan pada seluruh aspek kehidupan-sehari karena berpikir merupakan kunci utama dalam menjalani kehidupan.
Gambar.1 Kerangka Berpikir Penelitian

Remaja Panti Asuhan:

QMengalami permasalahan ekonomi dan keluarga.

口Kesepian tanpa keluarga.

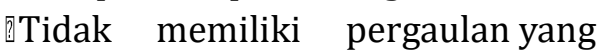
luas.

@Mendapatkan label negatif dari masyarakat.

口Shock karena merasa dibohongi oleh orang tua.
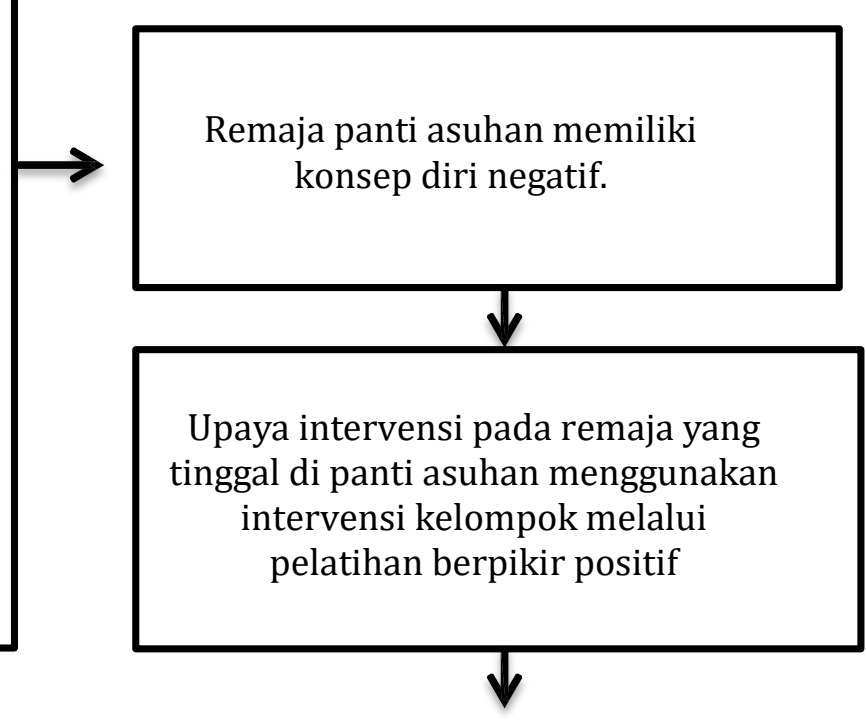

Pelatihan berpikir positif terletak pada aspek kognitif yang dapat mengubah pola pikir, hal ini erat kaitannya dengan konsep diri yang terbentuk dari keyakinan dan asumsi terhadap diri. Pelatihan ini menggunakan peer group untuk membentuk suatu dinamika kelompok yang akan mendorong terciptanya dukungan dalam kelompok. Peserta akan diberikan latihan-latihan berpikir positif.

Konsep Diri Positif

- Memahami kekuatan pikiran

- Menilai diri dan lingkungan secara obyektif.

- Menghargai kekuatan diri.

- Memusatkan pada harapan yang positif 


\section{HIPOTESIS PENELITIAN}

Pelatihan berpikir positif diduga mampu meningkatkan konsep diri remaja yang tinggal di panti asuhan.

\section{METODE PENELITIAN Rancangan Penelitian}

Penelitian ini merupakan penelitian kuantitatif. Sedangkan dalam jenisnya penelitian ini termasuk dalam penelitian quasi-experimental. Desain eksperimen yang digunakan adalah between subject design dimana pengukuran dilakukan pada subjek yang berbeda dalam situasi yang berbeda pula. Pada penelitian ini dua situasi tersebut adalah situasi sebelum diberikan intervensi dan setelah diberikan intervensi. Penelitian ini menggunakan model non randomized pre-test post test control group design dimana pre-test dan pos-test diberikan pada kelompok tersebut pada saat sebelum dan sesudah diberikan treatment. Rancangan penelitian dapat digambarkan pada tabel 1 dibawah ini:

Tabel 1. Rancangan Penelitian

\begin{tabular}{|l|l|l|l|}
\hline Kelompok & & $\begin{array}{l}\text { Rancangan } \\
\text { Penelitian }\end{array}$ & \\
\hline Kontrol & $\mathrm{X} 1$ & $\rightarrow$ & $\mathrm{X} 2$ \\
\hline Eksperimen & $\mathrm{X} 1$ & $\rightarrow \mathrm{Q}$ & $\overrightarrow{\mathrm{X} 2}$ \\
\hline
\end{tabular}

Keterangan:

$\mathrm{X} 1$ : pengukuran/pemberian skala sebelum dilakukan intervensi (Pre-test)

$\mathrm{Q}$ :pemberian intervensi atau perlakuan

$\mathrm{X} 2$ : pengukuran/pemberian skala sebelum dilakukan intervensi (Post-test)

\section{Subjek Penelitian}

Populasi remaja yang tinggal di panti asuhan Al-Hidayah Batu berjumlah 40 subjek. Subjek pada penelitian ini adalah 30 orang remaja yang tinggal di yayasan panti asuhan Al-Hidayah Batu pada rentang usia 13-17 tahun, yang memiliki skor skala konsep diri berada dalam kategori sedang dan rendah menggunakan purposive sampling. Purposive sampling adalah pengambilan sampel sesuai dengan yang dikehendaki oleh peneliti (Marliani, 2013). Sedangkan pembagian subjek ke dalam kelompok eksperimen dan kelompok kontrol dilakukan dengan menggunakan random assigment, yakni subjek ditempatkan secara acak ke dalam kelompok eksperimen dan kelompok kontrol.

\section{Instrumen Penelitian}

Pelatihan berpikir positif adalah suatu bentuk perlakuan yang diberikan peneliti yang menekankan pada emosi dan pikiran yang positif. Adapun bentuk kegiatan berupa materi, studi kasus, relaksasi, games, dan audio visual dalam satu waktu yang telah ditetapkan. Kegiatankegiatan tersebut memiliki manfaat untuk mengubah pandangan negatif remaja terhadap dri dan lingkungan.

Konsep diri adalah suatu keyaknian yang dimiliki individu mengenai dirinya dan bagaimana cara orang lain menilainya. Pada beberapa penelitian memaparkan bahwasanya remaja panti asuhan beresiko memiliki konsep diri negatif yang disebabkan faktor-faktor pengalaman negatif yang pernah dialami sebelum maupun saat tinggal di panti asuhan.

Adapun data penelitian diperoleh dari instrument penelitian menggunakan skala. Skala yang digunakan dalam penelitian ini adalah skala likert.masingmasing item diberikan 4 kategori skor jawaban yaitu: Sangat Setuju (SS), Setuju (S), Tidak Setuju (TS) dan Sangat Tidak Setuju (STS). Skala konsep diri dimodifikasi dari skala yang disusun oleh Firrotussalmah (2016) berdasarkan acuan teori Calhoun dan Acocella (1990) yang menyatakan 3 aspek sebagai berikut: pengetahuan, harapan dan penilaian. Responden diminta mengisi pernyataan dalam skala interval dengan jumlah aitem alat ukur sebanyak 72 aitem. Setelah itu dilakukan pengujicobaan alat ukur, hingga tersisa 40 aitem (indeks daya beda aitem antara 0,313-0,689) dan dengan Alpha Cronbach $=0,919$. 


\section{Prosedur dan Analisa Data Penelitian}

Pada umumnya, penelitian dan intervensi yang akan dilakukan memiliki tiga prosedur utama sebagai berikut:

1. Persiapan, pada tahapan persiapan dimulai dari peneliti melakukan pendalaman materi dan persiapan alat ukur skala yang digunakan serta simulasi modul pada subjek yang homogen. Setelah itu, peneliti meminta ijin untuk melakukan penelitian dan melaksanakan asesmen awal di yayasan panti asuhan Al- Hidayah Kota Batu. Peneliti menjelaskan rangkaian kegiatan serta tujuan dari penelitian kepada kepala yayasan AlHidayah Kota Batu serta menyusun jadwal yang tepat untuk proses pelaksanaan penelitian. Setelah perizinan dan mekanisme pelaksanaan sudah ditetapkan antara peneliti dan kepala yayasan AlHidayah Kota Batu, peneliti memulai melakukan asesmen awal dengan menyebarkan skala konsep diri kepada 36 subjek yang sesuai dengan kriteria penelitian yaitu remaja berusia 13-17 tahun. Peneliti menyeleksi skor subjek berdasarkan norma kelompok (tinggisedang-rendah). Setelah diperoleh hasil pre-test yaitu terdapat 30 subjek yang memiliki skor konsep diri sedang dan rendah, sedangkan 6 subjek tereliminasi karena memiliki skor konsep diri tinggi. Kemudian, peneliti mengelompokkan subjek ke dalam kelompok eksperimen dan kelompok kontrol secara random. Setelah mengelompokkan subjek, peneliti meminta kesedian secara langsung pada kelompok eksperimen untuk dapat mengikuti kegiatan penelitian dengan mengisi riwayat hidup dan menandatangai informed concent.

2. Tahap kedua adalah tahap intervensi, dimana subjek yang sudah terpilih diberikan intervensi berupa pelatihan berpikir positif. Sedangkan kelompok kontrol hanya diberikan pre-test dan post test. Pelatihan berpikir positif terdiri dari 4 sesi dalam dua kali pertemuan. Pada perencanaannya pelatihan akan meghabiskan waktu 8 jam. Namun, dalam pelaksanaannya hanya menghabiskan waktu 7 jam. Pada sesi 1 bernama The power of mind., kegiatan ini menggunakan metode ceramah mengenai kekuatan pikiran yang dikolaborasikan dengan studi kasus terkait pikiran negatif dan pikiran positif. Tujuan dari kegiatan ini adalah untuk menambah wawasan peserta terkait pengaruh kekuatan berpikir terhadap aspek-aspek kehidupan sehari-hari. Sesi 2 bernama Who is me. Metode yang digunakan pada sesi ini adalah metode permainan yang bertujuan untuk mengevaluasi diri berdasarkan penilaian diri dan orang lain. Sesi 3 bernama I'm very valuable. Metode yang digunakan pada sesi ini adalah metode relaksasi kesadaran indra yang bertujuan untuk memahami kelebihan diri dan menumbuhkan pengharapan positif terhadap diri. Berikutnya adalah sesi yang terakhir yaitu sesi 4, bernama Yes i can. Metode yang digunakan pada sesi ini adalah permainan dan audio visual. Tujuan dari kegiatan ini adalah untuk mengaplikasikan kelebihan diri untuk dapat bekerja sama dengan orang lain serta menumbuhkan pengharapan positif terhadap diri di masa mendatang. Pada tabel 3 merupakan deskripsi dari sesi-sesi dalam pelatihan berpikir positif yang digunakan.

3. Tahap ketiga adalah analisa data setelah seluruh rangkaian intervensi berakhir. Data-data yang diperoleh baik hasil pre-test dan post-test diinput dan diolah dengan menggunakan program SPSS for windows version 21. Teknik analisa data dalam penelitian ini menggunakan metode analisa data parametrik karena data-data yang diperoleh memenuhi syarat data parametrik yaitu: 
Tabel 2. Deskripsi Kegiatan Berpikir Positif Keterkaitan Kegiatan dengan Aspek Konsep Diri

\begin{tabular}{|l|l|}
\hline The power of mind & $\begin{array}{l}\text { Peserta akan diberikan materi mengenai kekuatan pikiran } \\
\text { melalui presentasi mengenai bagaimana proses berpikir dan } \\
\text { bagaiamana pikiran mempengaruhi aspek-aspek kehidupan } \\
\text { seperti: mindset, sikap, fisik, harga diri, kepercayaan diri dan } \\
\text { perasaan. Peserta juga akan diminta untuk menganalisa studi } \\
\text { kasus mengenai pemikiran negatif. Materi pada sesi ini } \\
\text { disesuaikan dengan materi kekuatan pikiran (Elfiky, 2015). }\end{array}$ \\
\hline Who is me? & $\begin{array}{l}\text { Peserta akan dilatih untuk memahami dirinya tidak berdasar pada } \\
\text { penilaiannya saja namun juga penilaian orang lain melalui } \\
\text { bermain games. Seluruh peserta akan dibagi menjadi dua } \\
\text { kelompok. Setiap individuakan mendapatkan lembar evaluasi diri. }\end{array}$ \\
& $\begin{array}{l}\text { Pertama-tama peserta akan mengisi data diri. Setelah itu, peserta } \\
\text { menjawab pertanyaan pertama mengenai "siapa saya" kemudian } \\
\text { dalam hitungan 1 menit, kertas tersebut harus berpindah pada } \\
\text { teman samping kanannya searah jarum jam. Setiap teman yang } \\
\text { mendapatkan lembar evaluasi diri akan menjawab pertanyaan } \\
\text { kedua mengenai "siapa saya menurutmu" sesuai dengan nama } \\
\text { pemilik masing-masing lembar evaluasi. }\end{array}$ \\
\hline I'm very valuable & $\begin{array}{l}\text { Lembar evaluasi akan terus berputar hingga kembali pada } \\
\text { pemiliknya masing-masing. }\end{array}$ \\
\hline $\begin{array}{l}\text { Trainer akan melatih peserta untuk menghargai kekuatan- } \\
\text { kekuatan yang ada di dalam dirinya melalui relaksasi kesadaran } \\
\text { indra. Peserta diminta untuk memejamkan mata dan } \\
\text { memvisualkan apa yang dikatakan oleh trainer. Selanjutnya } \\
\text { peserta diminta untuk menuliskan hal positif apa saja yang } \\
\text { pernah dilakukan dan bermanfaat untuk orang lain sebanyak- } \\
\text { banyaknya pada lembar kerja. }\end{array}$ \\
$\begin{array}{l}\text { Trainer akan melatih peserta untuk memusatkan perhatian pada } \\
\text { harapan yang positif dan optimisme melalui permaianan dan } \\
\text { video inspiratif. Pada metode permainan, peserta akan dibagi } \\
\text { menjadi tim dan dikolabrasikan dengan peserta yang memiliki } \\
\text { kelebihan yang bervariasi. Peserta dalam tim akan membentuk } \\
\text { sebuah perusahaan yang disesuaikan dengan kelebihan- } \\
\text { kelebihan yang dimiliki dalam tim. }\end{array}$ \\
\hline
\end{tabular}

memiliki data yang normal dan homogen dan jumlah subjek keseluruhan $=30$.

Uji asumsi yang dilakukan peneliti yaitu menggunakan Uji $t$-test untuk mengukur perbedaan (pretest-post-test) pada kelompok yang berbeda. Langkah pertama yaitu melakukan uji dua sampel tidak berhubungan (Independent Sample tTest ) untuk melihat perbedaan pretest pada kelompok eksperimen dan kelompok kontrol. Langkah kedua yaitu melakukan uji dua sampel berhubungan (Paired Sample t-Test) untuk melihat perbedaan masingmasing kelompok eksperimen dan kelompok kontrol setelah diberikan pre-test dan post-test. Langkah ketiga, kembali melakukan uji dua sampel tidak berhubungan (Independent Sample t-Test) untuk melihat perbedaan pada kelompok eksperimen yang telah diberikan 
perlakuan dibandingkan dengan kelompok kontrol. Selanjutnya, langkah terakhir yaitu peneliti membahas keseluruhan hasil analisa tersebut dengan penunjang hasil observasi dan wawancara. Langkah terakhir, peneliti mengambil kesimpulan penelitian.

\section{HASIL PENELITIAN}

Berdasarkan penelitian yang telah dilakukan, dilakukan uji analisis kuantitaif terhadap 30 subjek. Pemilihan subjek menggunakan metode purposive sampling yakni remaja yang tinggal di Yayasan panti asuhan Al-Hidayah Batu pada rentang usia 13-17 tahun dan memiliki skor skala konsep diri berada dalam kategori sedang dan rendah. Sedangkan pembagian subjek ke dalam kelompok eksperimen dan kelompok kontrol dilakukan dengan menggunakan random assigment, dimana subjek ditempatkan secara acak ke dalam kelompok eksperimen dan kelompok kontrol. Untuk lebih jelasnya deskripsi subjek telah dijabarkan menggunakan tabel dibawah ini:

Tabel 3. Karakteristik Subjek Penelitian

\begin{tabular}{|l|l|l|l|}
\hline & Kategori & $\begin{array}{l}\text { Kelompok } \\
\text { Eksperimen }\end{array}$ & $\begin{array}{l}\text { Kelompok } \\
\text { Kontrol }\end{array}$ \\
\hline Usia & Remaja & $13-15$ tahun & $13-17$ tahun \\
\hline Jenis Kelamin & Laki-Laki & 5 orang & 7 orang \\
\hline & Perempuan & 10 orang & 8 orang \\
\hline Skor Konsep Diri & $145-156$ (Tinggi) & - & - \\
\hline & $133-144$ & 12 orang & 12 orang \\
\hline & $114-121$ & 3 orang & 3 orang \\
\hline
\end{tabular}

Kemudian, peneliti melakukan uji hipotesis dan menghasilkan nilai t di bawah ini:

Tabel 4. Deskriptif Uji Independent Sample t-Test Data Pre-test dan Post-test Kelompok Eksperimen dan Kelompok Kontrol

\begin{tabular}{|c|c|c|c|}
\hline Kelompok & $\mathrm{N}$ & $\begin{array}{c}p \\
(\text { Sig } 2\end{array}$ & Kesimpulan \\
\hline $\begin{array}{c}\text { Eksperim } \\
\text { en }\end{array}$ & 1 & 0.003 & $\begin{array}{c}\text { Ada perbedaan } \\
\text { yang signifikan }\end{array}$ \\
\hline
\end{tabular}

Dari hasil Tabel 4 Independent Sampel $t$ Test, menunjukkan nilai $\mathrm{p}<0.05(\mathrm{p}=$ 0.003). Berdasarkan hasil analisis diambil keputusan bahwa terdapat perbedaan yang signifikan pada skor konsep diri antara kelompok eksperimen setelah diberikan perlakuan pelatihan berpikir positif dibandingkan dengan kelompok kontrol. Hasil pre-test dan post-test kelompok eksperimen menunjukkan adanya peningkatan skor konsep diri setelah diberikan perlakuan pelatihan berpikir positif. Sedangkan pada kelompok kontrol setelah diberikan pre-test dan post-test tidak menunjukkan perbedaan yang signifikan. Hal ini menunjukkan bahwa skor konsep diri pada kelompok eksperimen yang diberikan pelatihan berpikir positif lebih tinggi dibandingkan dnegan kelompok kontrol.

Berdasarkan hasil analisis kuantitatif yang telah dipaparkan dapat disimpulkan bahwa hipotesis yang diajukan dalam penelitian ini dapat diterima yaitu pelatihan berpikir positif mampu meningkatkan konsep diri remaja yang tinggal di panti asuhan Al-Hidayah Malang. Hasil penelitian menunjukkan bahwa skor konsep diri kelompok eksperimen lebih tinggi 
dibandingkan kelompok kontrol.

\section{DISKUSI}

Penelitian yang telah dilakukan menunjukkan adanya peningkatan konsep diri pada remaja yang tinggal di panti asuhan Al-Hidayah Kota Batu setelah diberikan pelatihan berpikir positif. Hal ini bermakna terjadi peningkatan konsep diri remaja yang tinggal di panti asuhan. Sedangkan pada kelompok kontrol yang tidak diberikan perlakuan tidak menunjukkan adanya perubahan yang signifikan. Berdasarkan perolehan skor pretest dan post-test kedua kelompok diperoleh hasil kelompok eksperimen mengalami kenaikan nilai skor konsep diri yang signifikan dibandingkan kelompok kontrol yang tidak menunjukkan adanya perubahan skor konsep diri yang signifikan.

Hasil penelitian di panti asuhan AlHidayah Batu menunjukkan naiknya ratarata skor skala konsep diri kelompok eksperimen dari pre-test dan post-test 15 subjek sebanyak $94 \%$ setelah diberikan perlakukan. Hasil penelitian ini sejalan dengan penelitian-penelitian yang telah dilakukan sebelumnya yang dilakukan oleh (Hidayat, Tri, \& Aditya, 2013) mengenai pelatihan berpikir positif terhadap konsep diri remaja difabel. Hasilnya menunjukkan bahwa pelatihan berpikir positif efektif meningkatkan konsep diri remaja difabel. Hal juga ini didukung oleh penelitian (Arya dkk., 2013) mengenai cognitive behavioral training untuk meningkatkan konsep diri dan sikap positif pada tahanan yang kecanduan terhadap narkoba. Pada penelitiannya, cognitive behavioral training terbagi menjadi dua untuk merubah sasaran yang berbeda, yaitu pelatihan kognitif untuk meningkatkan konsep diri pecandu narkoba dan pelatihan sikap untuk meningkatkan sikap positif pada pecandu narkoba. Pada penelitian ini, khususnya pelatihan kognitif memiliki kesamaan dengan pelatihan berpikir positif, yaitu sama-sama berfokus pada pendekatan kognitif untuk meningkatkan konsep diri remaja. Hasilnya menunjukkan bahwa cognitive behavioral training efektif meningkatkan konsep diri dan sikap positif pada tahanan pecandu narkoba. Berdasarkan hasil yang diperoleh ditunjang dengan penelitian terkait, dapat dikatakan bahwa pelatihan berpikir positif dapat meningkatkan konsep diri remaja yang tinggal di panti asuhan.

Berdasarkan temuan peneliti di panti asuhan Al-Hidayah Kota Batu, bahwa 83\% dari sampel remaja berusia 13-17 tahun yang tinggal di tempat tersebut memiliki skor konsep diri rendah dan sedang sedangkan $17 \%$ lainnya memiliki skor konsep diri tinggi. Menurut Mayaza dan Supradewi (2011) remaja panti asuhan cenderung percaya bahwa penderitaan atau kejadian yang tidak menyenangkan akan berlangsung lama dan mempengaruhi kehidupannya, mereka cenderung berpikiran negatif sehingga menambah rasa ketidakberdayaannya. Keadaan ini akan mempengaruhi individu dalam memandang dirinya. Menurut Calhoun dan Accocella (1990) konsep diri merupakan pandangan pribadi yang dimiliki seseorang tentang dirinya. Pandangan yang yang tidak teratur terhadap diri sendiri, tidak mengenal kekuatan dan kelemahan diri sendiri merupakan ciri dari individu yang memiliki konsep diri negatif. Dengan adanya pelatihan berpikir positif, remaja yang tinggal di panti asuhan akan dilatih untuk mengubah cara pandang terhadap diri dan lingkungan melalui pikiran dan emosi yang positif.

Pelatihan berpikir positif dirancang selama 4 (sesi) yang disusun berdasarkan aspek berpikir positif Alberch (dalam Tentama, 2014) meliputi: harapan yang positif, afirmasi diri (memusatkan pada kekuatan diri), pernyataan yang tidak menilai dan penyesuaian diri terhadap suatu kenyataan. Kegiatan dalam pelatihan berpikir positif disesuaikan dengan perkembangan kognitif dan sosioemosi remaja. Berdasarkan teori Piaget dalam (Santrock, 2013) remaja berada pada tahap operasional konkret, dimana pada masa ini pemikiran bersifat lebih abstrak dan tidak terbatas pengalamanpengalaman yang bersifat konkret. Pada periode ini memungkinkan terjadinya peningkatan berpikir kritis meliputi; kecepatan pemrosesan informasi, 
otomatisasi, memiliki kemampuan untuk mengkombinasi beberapa pengetahuan, dapat menggunakan strategi secara spontan dalam perencanaan, mempertimbangkan berbagai alternatif dan pengawasan kognitif. Ditinjau dari kemampuan perkembangan tersebut remaja akan mampu memahami materi yang diberikan dalam pelatihan berpikir positif meliputi: memahami kekuatan pikiran, mengidentifikasi kelemahan dan kelebihan diri, mengingat kejadian positif yang pernah dialami serta berkolaborasi dengan kelompok untuk menyusun harapan di masa depan. Kegiatan berkolaborasi dalam pelatihan ini juga disesuaikan dengan perkembangan sosioemosi remaja, karena pada masa remaja keberadaan teman menjadi sangat penting untuk memenuhi kebutuhan sosial (Santrock, 2013).

Metode yang digunakan pada sesi pertama adalah metode ceramah mengenai kekuatan pikiran. Pemberian materi terkait bagaimana kekuatan pikiran dapat mempengaruhi aspek-aspek pikiran itu sendiri, fisik, perasaan, sikap, kepercayaan diri dan harga diri. Hal ini sesuai dengan pendapat Melanie (2007) bahwa konsep diri seseorang yang negatif akan mengakibatkan rasa tidak percaya diri, tidak berani mencoba hal-hal baru, berpikiran untuk takut gagal, merasa diri bodoh, rendah diri, merasa tidak berharga, merasa tidak layak untuk sukses dan pesimis. Oleh karena itu, pada sesi pertama sangat penting untuk memberikan pemahaman terkait bagaimana pikiran dapat menyebabkan hal-hal baik dan buruk terjadi.

Metode yang digunakan pada sesi kedua adalah metode permainan. Permainan ini mencakup bagaimana peserta dapat menilai diri dan lingkungannya secara objektif. Hal ini sesuai dengan pemaparan Myers (2014) yang menyatakan bahwa konsep diri merupakan jawaban-jawaban seseoarang terkait pertanyaan "siapa saya". Sedangkan Gergen (dalam Worcel et al., 2000) menjelaskan konsep diri tidak terkecuali tetang seseorang yang memikirkan menengenai dirinya, namun juga mengenai apa yang orang lain pikirkan tentang kita.
Metode yang digunakan pada sesi ketiga adalah rilaksasi kesadaran indra, dimana seluruh peserta fokus pada hal-hal positif yang pernah dialami selama hidupnya. Berdasarkan penelitian Lawendownski dan Bieleninik (2017) bahwa penggunaan musik dapat menjadi media dalam mengembangkan pemahaman mengenai diri sendiri untuk menumbuhkan ekspresi baru dan identitas diri. Hal ini sesuai dengan pemaparan Calhoun dan Acocella (1990) bahwa individu yang memiliki konsep diri positif adalah individu yang mengetahui tentang dirinya, menerima sejumlah fakta yang sangat bermacam-macam mengenai dirinya.

Metode yang digunakan pada sesi empat adalah metode permainan dan audio visual. Pada sesi ini, peserta berkolaborasi membangun sebuah impian bersama untuk masa depan. Kegiatan permainan ini menekankan kerjasama dan kreatifitas yang mengasah kognitif dari masingmasing peserta. Pemberian video inspiratif diakhir sesi juga memberikan penguatan akan berharganya diri setiap individu. Hal ini berkaitan dengan pemaparan Calhoun dan Acocella (1990) bahwa pengharapan terhadap diri dapat menjadi kekuatan yang mendorong untuk mencapai masa depan.

Dengan melakukan seluruh rangkaian kegiatan pelatihan berpikir positif, semua sesi yang ada pada penelitian ini ditujukan untuk membangun pemikiran yang positif. Dimana, pemikiran merupakan sumber utama terbentuknya konsep diri individu. Menurut Calhoun dan Accocella (1990) konsep diri merupakan pandangan pribadi yang dimiliki seseorang tentang dirinya sendiri meliputi aspek: penggetahuan, pengharapan dan penilaian terhadap diri. Dengan membangun pemikiran dan mengolah emosi yang positif seluruh peserta remaja yang tinggal di panti asuhan Al-Hidayah Batu dapat meningkatkan konsep diri mereka. Keberhasilan dari penelitian ini juga ditunjang dengan hasil observasi yang diperoleh selama proses pemberian perlakukan pelatihan berpikir positif. Dimana, hampir seluruh peserta dapat terlibat secara aktif dan atusias dalam mengikuti pelatihan berpikir positif dan dapat saling terbuka sesama rekan lainnya. Kolaborasi dan keterbukaan antar peserta 
sangat membantu dalam membentuk suatu dinamika dalam proses penelitian ini. Hal ini sesuai dengan penelitian Rill et al., (2009) bahwa interaksi dengan teman sebaya adalah faktor yang berkontribusi paling signifikan dalam mempengaruhi pembentukan konsep diri.

Penelitian ini memiliki keterbatasan yang muncul saat penelitian yaitu, pada hari kedua pelaksanaan pelatihan ada dua peserta yang secara mendadak mendapatkan tugas dari pihak yayasan sehingga kedua pserta tidak dapat mengikuti kegiatan sesi 3 secara utuh. Hal ini dapat mempengaruhi hasil post-test dari salah satu subjek yang tidak mengalami kenaikan bahkan mengalami peneurunan skor konsep diri. Hambatan lainnya yaitu dari pihak peneliti untuk menemukan fasilitator yang dapat efektif membantu jalannya penelitian dan mencari jadwal penelitian yang tidak menganggu efektifitas jam belajar peserta.

\section{SIMPULAN DAN IMPLIKASI}

Penelitian ini menunjukkan bahwa pelatihan berpikir positif mampu meningkatkan konsep diri remaja yang tinggal di yayasan panti asuhan Al- Hidayah Batu. Implikasi dari penelitian ini meliputi:

Bagi panti asuhan, diharapkan pengasuh panti asuhan untuk dapat memberikan perhatian yang lebih intensif kepada remaja yang tinggal di panti asuhan. Dengan memberikan perhatian, maka remaja akan merasa bahwa dirinya adalah seseorang yang berharga dan hal ini dapat membantu dalam membangun konsep diri positif.

Bagi peneliti selanjutnya, daapat mengembangkan penelitian tidak terbatas remaja yang tinggal di panti asuhan saja, dapat dilakukan pada kalangan yang berpotensi memiliki konsep diri negatif.

\section{REFERENSI}

Agung, I.M. (20 Januari, 2016). Dinamika kelompok perspektif psikologi sosial. Diakses dari https://vano2000/2015/03/dinam ika-kelompok2.pdf.
Agustiani, H. (2006). Psikologi perkembangan pendekatan ekologi kaitannya dengan konsep diri. Bandung: PT.Refika Aditama.

Amalia, F.N. (2015). Hubungan konsep diri dengan resiliensi remaja pada keluarga orang tua tunggal. Skripsi, Fakultas Psikologi dan Fakultas Agama Islam Universitas Muhammadiyah Surakarta.

Arifin, Yanuar. (2011). 100\% bisa selalu berpikir positif. Yogyakarta: DIVA Press.

Arya, A.R.M., Mahmoud, S., Abbas, A.H.K., Fatemeh, L., Zohreh, H., Salar, D.S., \& Matloob, A.K. (2013). The effectiveness of cognitive-behavioral training on increasing self-concept's measure and the attitude style toward narcotic drugs in tonekabon addicted prisoners. Journal High Risk Behavior \& Addiction, 2(1), 39-42.

BPS Provinsi Jawa Timur. (2012). Jumlah anak terlantar di provinsi jawa timur tahun 2012. Diakses pada 01 Januari 2016, dari http://jatim.bps.go.id.

Calhoun, J., \& Acocella, J.R. (1990). Psikologi tentang penyesuaian dan hubungan kemanusiaan (Ed. 3). Alih bahasa : Prof. DR. Satmoko. Semarang: IKIP Press.

Corey,G. (2013). Teori dan praktek konseling \& psikoterapi (Cet.7). Bandung: PT Refika Aditama.

Dayakisni, T., Hudaniah. (2009). Psikologi sosial (Ed.revisi). Malang: UMM Press.

Departemen Sosial Republik Indonesia. (2004). Acuan umum pelayanan sosial anak di panti asuhan. Jakarta: Departemen Sosial RI.

Dwitantyanov, A., Farida, H., \& Dian, R.S. (2010). Pengaruh pelatihan berpikir positif pada efikasi diri akademik mahasiswa (studi eksperimen pada mahasiswa fakultas psikologi UNDIP Semarang). Jurnal Psikologi UNDIP, $8(02)$. 
Elfiky, I. (2015). Terapi berpikir positif. Jakarta: Penerbit Zaman.

Feist,J \& Feist G.J. (2009). Teori kepribadian (Ed. 7). Jakarta: Salemba Humanika.

Firotussalamah. (2016). Hubungan konsep diri dengan kecemasan narapidana remaja di LPKA kelas 1 blitar menjelang bebas. Skripsi, Fakultas Psikologi Universitas Islam Negeri Maulana Malik Ibrahim Malang.

Ghaderi, S., \& Barzigar, M. (2015). The impact of positive thingking on social adjustment of high school students in sardasht. Indian Journal of Fundamental and Applied Sciencess, 5, 2487-2494.

Gursoy, F., Mudriye, Y.B., Emel, O., Sema. B., Seyhan, C \& Ozlem, Y. (2012). Study on self-concept levels of adolescents in the age group of 13-18 who live in orphanage and those who do not live in orphanage. Journal of Social Sciences and Education, 2, 2223-4934.

Hidayat, I.C., Tri, R.A., \& Aditya, N.P. (2013). Pengaruh pelatihan berpikir positif terhadap peningkatan konsep diri pada remaja difabel di balai besar rehabilitasi sosial bina daksa (BBRSBD) Prof. Dr. Soeharso Surakarta. Jurnal Ilmiah Psikologi, 2, 64-204.

Lawendownsku, R., \& Bieleninik. (2017). Identity and self esteem ini the context of music and music therapy: a review. Journal Health Psychology, 5(2).

Lukman, M. (2000). Kemandirian anak asuh di panti asuhan yatim islam ditinjau dari konsep diri dan kompetensi interpersonal. Jurnal Psikologika, 5, 57-73.

Marliani, R. (2013). Psikologi eksperimen. Bandung: CV Pustaka Setia.

Mayaza, K.N., \& Supradewi, R. (2011). Konsep diri kebermaknaan hidup pada remaja di panti asuhan. Jurnal Psikologi, 6, 103-112.
Melanie, D. (2007). Pembentukan konsep diri siswa melalui pembelajaran partisipatif (sebuah alternatif pendekatan pembelajaran di sekolah dasar). Jurnal Pendidikan Penabur 8(7), 66-74.

Mohammadi,M., \& Adam, L.B. (2013). Effectiveness of positive thingking skills training on students happiness. Journal of European Psychiatry, 28.

Mousavi, E., Ali, E., \& Soodabeh, S.S. (2015). The effect of positive thinking on quality of life and resiliency of cancer patients. International Journal Medical Psychology, 3(3).

Mutambara, J. (2015). Enhancing psychosocial support through positive youth development:narratives from orphans in zimbabwe. Journal of Child \& Adolescent Behavior, 3(6).

Nurhani, R.A. (2013). Hubungan antara konsep diri dan penyesuaian diri pada remaja di islamic boarding school smpit daarul hikmah bontang. Artikel Penelitian, Fakultas Pendidikan Psikologi Universitas Negeri Malang, Malang.

Papalia D.E., Olds, S.W, \& Feldman, R.D. (2009). Human development (Perkembangan Manusia) (Ed. 10). Jakarta: Salemba Humanika.

Parry, G. (1990). Coping with stress. New York: The Birtsih. Psychological Society.

Peter, R. (2015). Peran orang tua dalam krisis remaja. Character building development centre. Jakarta: Universitas Binus.

Pomerantz, A. M. (2013). Psikologi klinis. Yogyakarta: Pustaka Pelajar.

PPK. (2009). Pola pengasuhan anak di panti asuhan dan pondok pesantren kota solo dan kabupaten klaten. Kerjasama Pusat Penelitian Kependudukan, LPPM UNS dengan UNICEF.

Pudjiyogyanti, C. R. (1988). Konsep diri dalam pendidikan. Jakarta: Arcan. 
Rakhmat, J. (2007). Psikologi

komunikasi. Bandung: Remaja

Rosdakarya.

Rill, L., Baiocchi, E., Hopper, M., Denker, K., \& Olson, L.N. (2009). Exploration of the relationship between self-esteem, commitment, and verbal aggressiveness in romantic dating relationships. Communication Reports, 22(2).

Rola, F. (2006). Konsep diri remaja penghuni panti asuhan. Penelitian Dosen. Medan: Universitas Sumatra Utara.

Sampthirao, P. (2016). Self concept and interpersonal communication. Journal of Indian Psychology, 3(6).

Seligman, M.E.P. (2008). Menginstal optimisme-how to change you mind and your life (Terjemahan). Bandung: Momentum
Shokhmgar, Z. (2016). Effectiveness of positive thingking skills into team approach to mental health and self esteem, of students torbat-e jam city. Journal of Internet Psychology,12(3). Accessed on January12, 2017 from http://ejbio.imedpub.com.

Tentama, F. (2014). Hubungan positive thinking dengan self-acceptance pada difabel (bawaan lahir) di SLB Negeri 3 Yogyakarta. Jurnal Psikologi Kognitif, 2(2), 1-7.

Worcel, S., Cooper, J., Goethals, G.R., \& Olson, J.M. (2000). Social psychology. America: Wadsworth. 